\title{
Peningkatan Prestasi Belajar Siswa MTs Al Mubarok Bandar Mataram Lampung Tengah
}

\author{
Arianto \\ STIT Al Mubarok
}

\begin{abstract}
Behavior change is one that can be seen is student achievement is the result or level of ability that has been achieved by students after following the teaching and learning process in a certain time either in the form of behavioral changes, skills and knowledge and then will be measured and assessed which then manifested in the numbers or statements. The learning process and its results can only be observed from changes in different behaviors that were previously in a person in terms of knowledge, affective and psychomotor. Broadly speaking, the learning process is influenced by duafaktor, namely internal factors and external factors. Internal factors include physiological factors, ie student body and psychological factors, ie students' intelligence or intelligence, motivation, interests, attitudes, talents. External factors include the natural environment and the socio-cultural environment, while the non-social or instrumental environment, ie the curriculum, the program, the learning facilities, the teacher.
\end{abstract}

Keywords: Learning chievement

\section{A. Pendahuluan}

Peserta didik adalah seseorang atau sekelompok orang sebagai pencari, penerima pelajaran yang dibutuhkannya, sedang pendidik adalah seseorang atau sekelompok orang yang berprofesi sebagai pengolah kegiatan belajar mengajar dan seperangkat peranan lainnya yang memungkinkan berlangsungnya kegiatan belajar mengajar yang efektif. Kegiatan belajar mengajar melibatkan beberapa komponen, yaitu peserta didik, guru (pendidik), tujuan pembelajaran, isi pelajaran, metode mengajar, media dan evaluasi.

Salah satu tujuan pembelajaran adalah perubahan tingkah laku yang positif dari peserta didik setelah mengikuti kegiatan belajar mengajar, seperti perubahan yang secara psikologis akan tampil dalam tingkah laku yang dapat diamati melalui alat indera oleh orang lain, baik tutur katanya, motorik dan gaya hidupnya.

Perubahan tingkah laku tersebut salah satu yang dapat dilihat adalah prestasi belajar siswa yaitu hasil atau taraf kemampuan yang telah dicapai siswa setelah mengikuti proses belajar mengajar dalam waktu tertentu baik berupa perubahan tingkah laku, keterampilan dan pengetahuan dan kemudian akan diukur dan dinilai yang kemudian diwujudkan dalam angka atau pernyataan.

Proses belajar dan hasilnya hanya dapat diamati dari perubahan tingkah laku yang berbedadari yang sebelumnya pada diri seseorang baik dalam hal pengetahuan, afektifmaupun psikomotor. Secara garis besar, proses belajar dipengaruhi oleh duafaktor, yaitu faktor internal dan faktor eksternal. Faktorfaktor internal meliputifaktor fisiologis, yaitu jasmani siswa dan faktor psikologis, yaitu kecerdasan atau intelegensi siswa, motivasi, minat, sikap, bakat. Faktor- faktor eksternal meliputi lingkungan alamiah dan lingkungan sosial budaya, sedangkan lingkungan non sosial atau instrumental, yaitu kurikulum, program, fasilitas belajar, guru. 
Hal ini senada dengan Ngalim Purwanto ${ }^{1}$ mengemukakan bahwa faktorfaktor yang mempengaruhi proses dan hasil belajar adalah faktor dalam dan faktor luar. Faktor dalam meliputi faktor fisiologi (kondisi fisik dan kondisi panca indera). Faktor psikologi diantaranya bakat, minat, kecerdasan, motivasi, kemampuan kognitif. Sedangkan faktor luar meliputi faktor lingkungan dan factor instrumental. Faktor lingkungan ialah faktor alam dan faktor sosial. Faktor instrumental adalah kurikulum/bahan pelajaran, guru/pengajar, sarana dan fasilitas, dan administrasi/manajemen sekolah. Muhibbin Syah 2 menambahkan bahwa " disamping faktorfaktor internaldan eksternal siswa, faktor pendekatan belajar juga berpengaruh terhadap tarafkeberhasilan proses pembelajaran siswa tersebut". Secara khusus SyaifulBahri Djamarah mengemukakan bahwa interaksi dari lingkungan alami danlingkungan sosial budaya selalu terjadi dalam mengisi kehidupan anak didik serta mempunyai pengaruh yang signifikan terhadap belajar anak di sekolah. ${ }^{3}$ Demikian halnya dengan fasilitas belajar, anak didik dapat belajar lebih baik dan menyenangkan bila suatu sekolah dapat memenuhi segala kebutuhan belajar anak. Masalah yang dihadapi oleh anak didik dalam belajar relatif kecil, sehingga hasil belajar anak didik akan lebih baik. Dari beberapa faktor dan tujuan pendidikan tersebut, maka sekolah perlu menyediakan fasilitas belajar yang dapat menunjang terlaksananya proses pendidikan dan peningkatan kualitas pendidikan. Fasilitas tersebut dapat berupa prasarana yang menunjang dan dapat membantu peserta didik untuk menemukan berbagai pengetahuan yang dibutuhkan serta mendorong peserta didik untuk aktif melibatkan diri dalam proses pembelajaran. Selain menyediakan fasilitas belajar, sekolah juga perlu menciptakan lingkungan yang mendukung dalam proses pembelajaran sehingga peserta didik dapat belajar dengan baik dan dapat meningkatkan prestasi belajarnya.

Terpenuhinya fasilitas belajar seperti sarana prasarana dalam belajar dan adanya kondisi lingkungan belajar yang baik dapat mendukung proses pembelajaran sehingga kegiatan belajar mengajar (KBM) berlangsung secara efektif dan efisien. Pembelajaran yang efektif dan efisien dapat meningkatan prestasi belajar siswa. Terlebih lagi dewasa ini semakin dirasakan betapa pentingnya peranan fasilitas dan lingkungan yang baik dalam pembelajaran agar tercapai tujuan pendidikan yang diharapkan. Namun, pentingnya keberadaan fasilitas dan lingkungan yang baik, seringkali terabaikan. Hal ini, terbukti dengan seringnya pemberitaan baik di media cetak maupun media elektronik mengenai potret buram pendidikan di tanah air. Dalam pemberitaan tersebut sering kali mengeluhkan adanya bangunan sekolah yang roboh atau rusak dan ironisnya yang kurang mendapat perhatian dari pemerintah baik pemerintah setempat maupun pemerintah pusat. Hal tersebut tentunya akan sangat menghambat proses belajar karena proses belajar tidak dapat berlangsung dengan baik dan lancar sesuai dengan yang diharapkan. Jika proses belajar tidak dapat berlangsung dengan baik dan lancar, maka tujuan dari pembelajaran juga tidak akan dapat tercapai dengan baik. Hal ini juga akan berdampak pada

\footnotetext{
${ }^{1}$ M.Ngalim Purwanto,Psikologi Pendidikan, Bandung :Remaja Rosdakarya,2007, h.106

${ }^{2}$ Muhibbin Syah Psikologi Belajar, (Jakarta: Rajawali Pers, 2011), h.156

${ }^{3}$ Syaiful Bahri Djamarah,Psikologi Belajar. Jakarta: Rineka Cipta 2008., h.177
}

| RI'AYAH, Vol. 4 No. 01 Januari-Juni 2019 
prestasi siswa yang nantinya merujuk pada kualitas lembaga sekolah dan pada akhirnya berujung pada pemerintah.

Fasilitas dan lingkungan belajar merupakan faktor yang sama-sama berasal dari luar diri siswa yang biasanya berpengaruh secara tidak langsung terhadap peningkatan prestasi siswa. Akan tetapi, tidak tersedianya fasilitas dan lingkungan belajar yang baik dapat menjadi masalah dan penghambat proses belajar dan pencapaian prestasi belajar yang baik oleh karena terabaikan ketersediaannya. Pencapaian prestasi belajar yang baik menunjukkan keberhasilan dalam proses pembelajaran, begitu juga sebaliknya tidak tercapainya prestasi belajar yang baik menunjukkan kurang berhasilnya dalam proses pembelajaran. Pemenuhan dan pengelolaan fasilitas dan lingkungan belajar yang baik untuk kelancaran proses belajar perlu diperhatikan oleh setiap sekolah. Sebab, terpenuhinya fasilitas dan lingkungan yang baik, dapat meminimalisir kesulitan belajar yang dialami oleh peserta didik. Tingkat kesulitan belajar yang rendah, menciptakan kelancaran proses belajar sehingga terjadi peningkatan prestasi belajar siswa.

Menurut Gleitman dan Reber dalam Muhibbin Syah bahwa motivasi dipahami sebagai keadaan internal organisme, baik manusia ataupun hewan yang mendorongnya untuk berbuat sesuatu. Dalam pengertian ini, motivasi berarti pemasok daya untuk bertingkah laku secara terarah ${ }^{4}$. Demikian juga dalam kegiatan belajar mengajar (selanjutnya disingkat KBM) motivasi belajar juga merupakan daya bagi pencapaian tujuan pembelajaran.

Berdasarkan hasil prasurvei sementara yang dilakukan, prestasi belajar siswa belum mencapai standar yang telah ditentukan. Hal ini dapat terlihat dari ketiga aspek yang ada yaitu aspek kognitif, yang ditandai dengan belum mencapai kriteria ketuntasan belajar yang telah ditetapkan oleh madrasah. Dalam aspek afektif siswa belum menganggap penting dan bermanfaat pendidikan agama Islam dalam kehidupannya hal ini tercermin dalam tingkah lakukanya sehari-hari di lingkungan madrasah. Dalam aspek psikomotor ditemukan rendahnya tingkat kemampuan melafalkan atau mengucapkan materi-materi al-qur'an dah hadist yang telah ditetapkan dalam kurikulum. Mengingat pentingnya peran madrasah dalam upaya peningkatan mutu pendidikan, maka kondisi lingkungan dan motivasi belajar di madrasah ikut menentukan kualitas dan prestasi belajar siswa. Seperti apa yang sudah ada di MTs Al Mubarok Bandar Mataram Lampung Tengah, Madrasah ini memiliki pendidik yang berkualitas serta dalam proses pembelajaran pendidikpun sesuai dengan potensi yang dimiliki. Selain itu fasilitas yang menunjang dalam kegiatan proses pembelajaran antara lain: perpustakaan, laboratorium, lapangan olahraga, ruang kelas dan lain-lain.Sementara itu berdasarkan hasil prasurvey yang penulis laksanakan pada tanggal 15 Mei 2017 diperoleh nilai hasil belajar siswa yaitu dari 31 siswa terdapat 17 orang siswa yang belum tuntas belajar, di sekolah ini kebiasaan belajar yang dilakukan oleh peserta didik sudah cukup maksimal serta lingkungan belajar di sekolah inipun sebenarnya cukup mendukung terciptanya proses pembelajaran yang baik akan tetapi masih banyak peserta didik yang mendapatkan nilai rata-rata di bawah Kriteria Ketuntasan Minimal

${ }^{4}$ Muhibbin Syah, Psikologi Pendidikan Dengan Pendekatan Baru.( Bandung: PT. Remaja Rosdakarya: 2003), h.136.

| RI'AYAH, Vol. 4 No. 01 Januari-Juni 2019 
(KKM). Berdasarkan wawancara dengan wakil kepala sekolah bahwa Kriteria Ketuntasan Minimal (KKM) yang telah disepakati oleh sekolah dan guru adalah 75 dengan menimbang kesulitan pelajaran. ${ }^{5}$ Begitu pentingnyametode mengajar guru dan motivasi belajar dengan prestasi belajar siswa.

\section{B. Pembahasan}

\section{Pengertian Prestasi Belajar}

Prestasi menurut Kamus Besar Bahasa Indonesia adalah hasil yang telah dicapai. ${ }^{6}$ Menurut W. S. Winkel, prestasi adalah bukti keberhasilan usaha yang dapat dicapai. ${ }^{7}$ Sedangkan menurut Mas'ud Hasan Abdul Dahar sebagaimana dikutip oleh Djamarah bahwa prestasi adalah apa yang telah dapat diciptakan, hasil pekerjaan, hasil yang menyenangkan hati yang diperoleh dengan jalan keuletan kerja secara individu maupun secara kelompok. ${ }^{8}$

Dari pengertian yang dikemukakan tersebut di atas, jelas terlihat persamaan pengertian dari prestasi, perbedaannya hanya pada kata-kata tertentu sebagai penekanan, namun intinya sama yaitu hasil yang dicapai dari suatu kegiatan. Untuk itu, dapat disimpulkan bahwa prestasi adalah hasil dari suatu kegiatan yang telah dikerjakan, diciptakan, yang menyenangkan hati, yang diperoleh dengan jalan keuletan kerja, baik secara individual maupun secara kelompok dalam bidang kegiatan tertentu.

Belajar menurut Kamus Besar Bahasa Indonesia adalah berusaha memperoleh kepandaian atau ilmu. ${ }^{9}$ Menurur Skiner belajar adalah suatu proses adaptasi atau penyesuaian tingkah laku yang berlangsung sangat progresif. ${ }^{10}$ Menurut Slameto bahwa belajar adalah suatu proses usaha yang dilakukan seseorang untuk memperoleh suatu perubahan tingkah laku yang baru secara keseluruhan, sebagai hasil pengalamannya sendiri dalam interaksi dengan lingkungannya. ${ }^{11}$

Menurut Hamzah B. Uno, belajar adalah perubahan tingkah laku secara relatif permanen dan secara potensial terjadi sebagai hasil dari praktik atau penguatan (reinforced practice) yang dilandasi tujuan untuk mencapai tujuan tertentu. ${ }^{12}$

Berdasarkan beberapa pendapat yang telah dikemukakan di atas, dapat diambil suatu kesimpulan tentang hakekat dari belajar adalah suatu perubahan seluruh tingkah laku yang terjadi dalam diri individu yang relatif menetap sebagai hasil pengalaman dan interaksi. Namun tidak setiap perubahan yang terjadi dalam individu merupakan hasil dari proses belajar. Suatu perubahan

\footnotetext{
${ }^{5}$ Hasil pra survai wawancara dengan Waka kesiswaan MTs Al-Mubarok pada tanggal 15 Mei 2017

${ }^{6}$ Depdikbud, Kamus Besar Bahasa Indonesia, (Jakarta: Balai Pustaka, 1990), h. 700.

7 W. S. Winkel, Psikologi Pendidikan dan Evaluasi Belajar, (Jakarta: PT Gamedia, 1986), h. 162.

${ }^{8}$ Djamarah, Syaiful Bahri, Prestasi Belajar dan Kompetensi Guru, (Surabaya: Usaha Nasional, 1994), h. 19

${ }^{9}$ Depdikbud,... h. 13.

${ }^{10}$ Muhibbin Syah,... h. 88.

${ }^{11}$ Slameto. Belajar dan Faktor-Faktor yang Mempengaruhinya. (Jakarta: Rineka Cipta, 2010), h.2.

${ }^{12}$ Hamzah B. Uno, Teori Motivasi danPengukurannya Analisis Di Bidang Pendidikan, (Jakarta: Bumi Aksara, 2006), h. 23.
}

| RI'AYAH, Vol. 4 No. 01 Januari-Juni 2019 
dapat dikatakan sebagai suatu proses belajar apabila memiliki ciri-ciri tertentu. Menurut Slameto ciri-ciri proses belajar adalah:

1) Perubahan terjadi secara sadar

2) Perubahan dalam belajar bersifat kontinyu dan fungsional

3) Perubahan dalam belajar bersifat aktif dan positif

4) Perubahan dalam belajar bukan bersifat sementara

5) Perubahan dalam belajar bertujuan atau terarah

6) Perubahan mencakup seluruh aspek tingkah laku. ${ }^{13}$

Prestasi belajar menurut W. S. Winkel adalah proses belajar yang dialami oleh murid menghasilkan perubahan dalam bidang pengetahuan, perubahan dalam bidang ketrampilan, dalam bidang nilai dan sikap, adanya nilai ini tampak dalam prestasi belajar yang dihasilkan oleh murid terhadap pertanyaan yang diberikan oleh guru di sekolah. ${ }^{14}$ Menurut Ngalim Purwanto, prestasi belajar adalah hasil-hasil pelajaran yang diberikan guru kepada muridnya atau oleh dosen kepada mahasiswa dalam jangka waktu tertentu. ${ }^{15}$

Sedangkan Nurkencana mengemukakan bahwa adalah hasil yang telah dicapai atau diperoleh anak berupa nilai prestasi belajar mata pelajaran. Ditambahkan bahwa prestasi belajar merupakan hasil yang mengakibatkan perubahan dalam diri individu sebagai hasil dari aktivitas dalam belajar. ${ }^{16}$

Menurut Djamarah, prestasi belajar adalah hasil yang di peroleh berupa kesan-kesan yang mengakibatkan perubahan dalam diri individu sebagai hasil dari aktivitas dalam belajar. ${ }^{17}$ Sedangkan menurut Sukmadinata prestasi belajar adalah realisasi atau pemekaran dari kecakapan-kecakapan potensial atau kapasitas yang dimiliki seseorang. ${ }^{18}$

Berdasarkan uraian di atas, maka dapat disimpulkan bahwa prestasi belajar adalah hasil atau taraf kemampuan yang telah dicapai siswa setelah mengikuti proses belajar mengajar dalam waktu tertentu baik berupa perubahan tingkah laku, keterampilan dan pengetahuan dan kemudian akan diukur dan dinilai yang diwujudkan dalam angka atau pernyataan dalam rapot. Pada umumnya penilaian yang mencakup dari nilai ulangan harian, nilai mid semester, nilai tugas, nilai ujian akhir semester, dan sebagainya.

\section{Aspek-Aspek Prestasi Belajar}

Prestasi belajar adalah hasil akhir yang diharapkan dapat dicapai setelah seseorang belajar. Adapun hasil belajar tersebut menurut Gagne sebagaimana yang dikutip oleh Slameto menyatakan bahwa hasil belajar dibedakan menjadi lima aspek, yaitu: keterampilan motoris, informasi verbal, kemampuan intelektual, strategi kognitif, dan sikap. ${ }^{19}$

Pendapat lain diberikan Benjamin S. Bloom dalam Winkel bahwa bahwa hasil belajar diklasifikasikan ke dalam tiga ranah yaitu ranah kognitif (cognitive

\footnotetext{
${ }^{13}$ Slameto,..., hh. 3-4.

${ }^{14}$ W. S. Winkel, Psikologi Pengajaran, (Yogyakarta: Media Abadi, 2007), h. 101.

${ }^{15}$ Ngalim Purwanto, Teknik-Teknik Evaluasi, (Jakarta: Roda Pengetahun, 1983), h. 25.

${ }^{16}$ Nurkencana. Evaluasi Hasil Belajar Mengajar. (Surabaya: Usaha Nasional. 2005) .h.62

${ }^{17}$ Syaiful Bahri Djamarah, Psikologi Belajar,(Jakarta: Rineka Cipta, 2002), h.156.

${ }^{18}$ Nana Syaodih Sukmadinata, Landasan Psikologi Proses Pendidikan, (Bandung : Remaja Rosdakarya, 2003), h. 101.

${ }^{19}$ Slameto,... h...14-15.
}

| RI'AYAH, Vol. 4 No. 01 Januari-Juni 2019 
domain), ranah afektif (affective domain) dan ranah psikomotor (psychomotor domain). ${ }^{20}$

Bertolak dari pendapat tersebut di atas, penulis lebih cenderung kepada pendapat Benjamin S. Bloom. Kecenderungan ini didasarkan pada alasan bahwa ketiga ranah yang diajukan lebih mudah terukur, dalam artian bahwa untuk mengetahui prestasi belajar yang dimaksudkan mudah dan dapat dilaksanakan, khususnya pada pembelajaran yang bersifat formal selain itu ketiga ranah tersebut dianggap penting dan diharapkan dapat mencerminkan perubahan yang terjadi sebagai prestasi belajar siswa, baik yang berdimensi cipta dan rasa maupun yang berdimensi karsa yang biasanya dinyatakan dalam bentuk nilai yang diperoleh siswa setelah dilakukan evaluasi atau tes.

Berdasarkan hal tersebut, maka penulis berkesimpulan bahwa jenis prestasi belajar itu meliputi 3 (tiga) ranah atau aspek, yaitu: 1) ranah kognitif (cognitive domain); 2) ranah afektif (affective domain); dan 3) ranah psikomotor (psychomotor domain).

Pengungkapan hasil belajar ideal meliputi segenap ranah psikologis yang berubah sebagai akibat pengalaman dan proses belajar siswa. Namun demikian, pengungkapan perubahan tingkah seluruh ranah itu, khususnya ranah rasa murid sangat sulit. Hal ini disebabkan perubahan hasil belajar itu ada yang bersifat intangible (tak dapat diraba).

Oleh karena itu, yang dapat dilakukan guru dalam hal ini adalah hanya mengambil cuplikan perubahan tingkah laku yang dianggap penting dan diharapkan dapat mencerminkan perubahan yang terjadi sebagai hasil belajar siswa, baik yang berdimensi cipta (kognitif) dan rasa (afektif) maupun berdimensi karsa (psikomotor).

Untuk memperoleh ukuran dan data hasil belajar siswa sebagaimana terurai di atas adalah mengetahui garis-garis besar indikator (penunjuk adanya prestasi tertentu) dikaitkan dengan jenis prestasi yang hendak diungkapkan atau diukur. Indikator- indikator prestasi belajar tersebut adalah sebagai berikut:

1. Ranah cipta (kognitif)

a) Pengamatan, indikatornya adalah: dapat menunjukkan; dapat membandingkan; dapat menghubungkan.

b) Ingatan, indikatornya adalah: dapat menyebutkan; dapat menunjukkan kembali.

c) Pemahaman, indikatornya adalah: dapat menjelaskan; dapat mendefinisikan dengan lisan sendiri.

d) Aplikasi, indikatornya adalah: dapat memberikan contoh; dapat menguraikan secara tepat.

e)Analisis, indikatornya adalah: dapat menguraikan; dapat mengklasifikasikan/memilah-milah.

f) Sintesis, indikatornnya adalah: dapat menghubungkan materimateri, sehingga menjadi kesaatuan baru; dapat menyimpulkan; dapat menggeneralisasikan.

2. Ranah rasa (afektif)

a)Penerimaan, indikatornya adalah: menunjukkan sikap menerima; menunjukkan sikap menolak.

${ }^{20}$ W. S. Winkel, Psikologi Pengajaran,... h. 272.

| RI'AYAH, Vol. 4 No. 01 Januari-Juni 2019 
b) Sambutan, indikatornya adalah kesediaan berpartisipasi/terlibat; kesediaan memanfaatkan

c)Apresiasi, indikatornya adalah: menganggap penting dan bermanfaat; menganggap indah dan harmonis; mengagumi.

d) Internalisasi, indikatornya adalah: mengakui dan meyakini; mengingkari

e)Karakterisasi, indikatornya adalah: melembagakan atau meniadakan; menjelmakan dalam pribadi dan perilaku seharihari.

3. Ranah karsa (psikomotor)

a) Ketrampilan bergerak dan bertindak, indikatornya adalah: kecakapan menggkoordinasikan gerak mata, tangan, kaki, dan anggota tubuh lainnya.

b) Kecakapan ekspresi verbal dan non verbal, indikatornya adalah: kefasihan melafalkan/mengucapkan; kecakapan dan gerakan jasmani. ${ }^{21}$

\section{Indikator Prestasi Belajar}

Indikator dijadikan sebagai tolok ukur dalam menyatakan bahwa prestasi belajar dapat dinyatakan berhasil apabila memenuhi ketentuan kurikulum yang disempurnakan. Pada dunia pendidikan, pengukuran prestasi belajar sangat diperlukan. Karena dengan diketahui prestasi siswa maka diketahui pula kemampuan dan keberhasilan siswa dalam belajar. Untuk mengetahui prestasi belajar dapat dilakukan dengan cara memberikan penilaian atau evaluasi dengan tujuan supaya siswa mengalami perubahan secara positif.

Menurut Muhibbin Syah, evaluasi adalah penilaian terhadap tingkat keberhasilan siswa mencapai tujuan yang telah ditetapkan dalam sebuah progam. ${ }^{22}$ Hal ini dapat dilihat dari sejauh mana perubahan yang telah terjadi melalui kegiatan belajar mengajar.

Pengajaran harus mengetahui sejauh mana siswa akan mengerti bahan yang akan diajarkan. Penilaian sumber informasi tentang hasil pengajaran yang telah disajikan. Pengukuran prestasi belajar tersebut dapat menggunakan suatu alat untuk mengevaluasi yaitu test. Test dipakai untuk memulai hasil belajar siswa dan hasil belajar mengajar dari pendidik.

Lebih lanjut menurut Muhibbin Syah Untuk mengetahui prestasi belajar siswa dapat dilakukan dengan cara memberi penilaian atau evaluasi yaitu untuk memeriksa kesesuian antara apa yang diharapkan dan apa yang tercapai, hasil penelitian tersebut dapat digunakan untuk memperbaiki dan mendekatkan tujuan yang diinginkan.

Berdasarkan uraian-uraian diatas dapat diambil kesimpulan bahwa pengukuran prestasi belajar dapat dilakukan dengan cara memberi penilaian atau evaluasi. Penilaian atau evaluasi yang dilakukan dapat diketahui dengan menggunakan suatu test tertulis atau test lisan yang mencakup semua materi yang diajarkan dalam jangka waktu tertentu. Dalam penelitian ini, penulis

${ }^{21}$ Muhibbin Syah, Psikologi Belajar, (Jakarta: Rajawali Pers, 2011), ed. Revisi ke-11, hh.216-217.

${ }^{22}$ Muhibbin Syah, Psikologi Pendidikan,... h.139.

| RI'AYAH, Vol. 4 No. 01 Januari-Juni 2019 
menggunakan data dokumentasi berupa nilai rapot yang dinyatakan dalam bentuk angka yang diperoleh dari proses belajar selama satu semester.

\section{Faktor-faktor yang Mempengaruhi Prestasi Belajar}

Prestasi belajar yang dicapai siswa di sekolah adalah bukti dari keberadaanya dan merupakan titik kulminasi dari aktifitasnya dalam proses belajar mengajar. Keberhasilan siswa untuk mendapatkan prestasi belajar banyak faktor-faktor yang mempengaruhinya.

Adapun faktor-faktor yang mempengaruhi prestasi belajar adalah:

1) Faktor dari dalam diri siswa (intern)

Sehubungan dengan faktor intern ini ada tingkat yang perlu dibahas menurut Slameto, yaitu faktor jasmani, faktor psikologi dan faktor kelelahan. ${ }^{23}$

a) Faktor Jasmani, dalam faktor jasmaniah ini dapat dibagi menjadi dua yaitu faktor kesehatan dan faktor cacat tubuh.

b) Faktor psikologis, dapat berupa intelegensi, perhatian, bakat, minat, motivasi, kematangan, kesiapan.

c)Faktor kelelahan yaitu kelelahan jasmani dan kelelahan rohani.

Dari uraian di atas maka kelelahan jasmani dan rohani dapat mempengaruhi prestasi belajar dan agar siswa belajar dengan baik haruslah menghindari jangan sampai terjadi kelelahan dalam belajarnya seperti lemah lunglainya tubuh.

Sehingga perlu diusahakan kondisi yang bebas dari kelelahan rohani seperti memikirkan masalah yang berarti tanpa istirahat, mengerjakan sesuatu karena terpaksa tidak sesuai dengan minat dan perhatian. Ini semua besar sekali pengaruhnya terhadap pencapaian prestasi belajar siswa. Agar siswa selaku pelajar dengan baik harus tidak terjadi kelelahan fisik dan psikis.

2) Faktor yang berasal dari luar (faktor ekstern).

a) Faktor keluarga sangat berperan aktif bagi siswa dan dapat mempengaruhi dari keluarga antara lain: cara orang tua mendidik, relasi antara anggota keluarga, keadaan keluarga, pengertian orang tua, keadaan ekonomi keluarga, latar belakang kebudayaan dan suasana rumah.

b) Faktor sekolah dapat berupa cara guru mengajar, ala-alat pelajaran, kurikulum, waktu sekolah, interaksi guru dan murid, disiplin sekolah, dan media pendidikan.

c)Faktor Lingkungan Masyarakat, faktor yang mempengaruhi terhadap prestasi belajar siswa antara lain teman bergaul, kegiatan lain di luar sekolah dan cara hidup di lingkungan keluarganya.

Menurut Ngalim Purwanto faktor-faktor yang mempengaruhi prestasi belajar adalah:

1) Faktor luar

a) Lingkungan meliputi alam dan sosial

b) Instrumental meliputi: kurikulum/bahan pelajaran, guru/pengajar, sarana dan fasilitas, administrasi/manajemen.

2) Faktor dalam

${ }^{23}$ Slameto,.... h. 54-72.

| RI'AYAH, Vol. 4 No. 01 Januari-Juni 2019 
a) Fisiologi meliputi: kondisi fisik, kondisi panca indera.

b) Psikologi meliputi: bakat, minat, kecerdasan, motivasi, dan kemampuan kognitif. ${ }^{24}$

Semua faktor yang telah disebutkan di atas, harus diperhatikan sedemikian rupa, sehingga dapat membantu dan menguntungkan serta menimbulkan rasa aman dalam proses belajar mengajar dengan seefesien dan seefektif mungkin sehingga berdampak pada prestasi belajar siswa.

\section{Kesimpulan}

Berdasarkan pengertian tersebut, maka kerangka pikir dalam penelitian ini adalah: lingkungan belajar dan motivasi belajar mempunyai hubungan dengan prestasi belajar MTs Al Mubarok Bandar Mataram Lampung Tengah, semakin baik lingkungan belajar pengukuran prestasi belajar dapat dilakukan dengan cara memberi penilaian atau evaluasi. Penilaian atau evaluasi yang dilakukan dapat diketahui dengan menggunakan suatu test tertulis atau test lisan yang mencakup semua materi yang diajarkan dalam jangka waktu tertentu.

\section{Daftar Pustaka}

Depdikbud, Kamus Besar Bahasa Indonesia, (Jakarta: Balai Pustaka, 1990)

Djamarah, Syaiful Bahri, Prestasi Belajar dan Kompetensi Guru, (Surabaya: Usaha

Nasional, 1994), Slameto. Belajar dan Faktor-Faktor yang Mempengaruhinya.

(Jakarta: Rineka Cipta, 2010).

Hamzah B. Uno, Teori Motivasi danPengukurannya Analisis Di Bidang Pendidikan, (Jakarta: Bumi Aksara, 2006)

Hasil pra survai wawancara dengan Waka kesiswaan MTs Al-Mubarok pada tanggal 15 Mei 2017

M.Ngalim Purwanto,Psikologi Pendidikan, Bandung :Remaja Rosdakarya,2007 Muhibbin Syah Psikologi Belajar, (Jakarta: Rajawali Pers, 2011).

Syaiful Bahri Djamarah, Psikologi Belajar. Jakarta: Rineka Cipta 2008.

Muhibbin Syah, Psikologi Pendidikan Dengan Pendekatan Baru.( Bandung: PT.

Remaja Rosdakarya: 2003).

Muhibbin Syah, Psikologi Belajar, (Jakarta: Rajawali Pers, 2011).

Nana Syaodih Sukmadinata, Landasan Psikologi Proses Pendidikan, (Bandung:

Remaja Rosdakarya, 2003).

Ngalim Purwanto, Teknik-Teknik Evaluasi, (Jakarta: Roda Pengetahun, 1983).

Ngalim Purwanto,Psikologi Pendidikan, (Bandung: PT Remaja Rosdakarya, 2011).

Nurkencana. Evaluasi Hasil Belajar Mengajar. (Surabaya: Usaha Nasional. 2005).

Syaiful Bahri Djamarah, Psikologi Belajar,(Jakarta: Rineka Cipta, 2002).

W. S. Winkel, Psikologi Pendidikan dan Evaluasi Belajar, (Jakarta: PT Gamedia, 1986).

W. S. Winkel, Psikologi Pengajaran, (Yogyakarta: Media Abadi, 2007).

${ }^{24}$ Ngalim Purwanto,Psikologi Pendidikan, (Bandung: PT Remaja Rosdakarya, 2011), h.107.

| RI'AYAH, Vol. 4 No. 01 Januari-Juni 2019 